\title{
THE IMPACT OF INDOOR CYCLING TRAINING ON HEMODYNAMIC PARAMETERS OF THE LEFT VENTRICLE OF MEN WITH ISCHAEMIC HEART DISEASE OR AFTER MYOCARDIAL INFARCTION
}

\author{
Gloc D. D. ${ }^{1}$, Nowak Z. ${ }^{2}$
}

Aim. Younger age of the cardiac patients somehow necessitates the use of modern forms of physical training, which become alternative and interesting means to provide effective rehabilitation. One such form is endurance Indoor Cycling training In the present study attempts to determine the impact of 1-month Indoor Cycling training on hemodynamic left ventricle parameters of men with ischemic heart disease or after myocardial infarction were made.

Material and methods. The study group consisted of 50 men under the model A of the $2^{\text {nd }}$ phase of cardiac rehabilitation ( 20 men of the Indoor Cycling group, IC, 20 men rehabilitated accordingly to the recommendations of the Polish Cardiac Society - a standard group, ST and 10 people who did not participate in any cardiac rehabilitation program - a control group, $\mathrm{C}$ ). The average age of all patients was $56,60 \pm 8,25$ years, the average left ventricular ejection fraction was $56 \% \pm 4,00$.

Results. Echocardiogram did not show significant changes after 1-month of training in both groups undergoing comprehensive cardiac rehabilitation. Paralleled to the preliminary study in the group of patients who refused to participate in the cardiac rehabilitation, results showed a reduction in all echocardiographic parameters, including a significant decrease in the left ventricular end diastolic diameter ( 52,80 vs $50,50 \mathrm{~mm}$ ) and volume (134,85 vs $121,88 \mathrm{ml}$; both variables at $p<0,001)$, as well as in the left ventricular mass $(239,46$ vs $208,61 \mathrm{~g} ; \mathrm{p}=0,002)$ and the left ventricular mass index $\left(123,52\right.$ vs $\left.107,61 \mathrm{~g} / \mathrm{m}^{2} ; \mathrm{p}=0,001\right)$.

Conclusion. No negative influence of the Indoor Cycling training on morphological parameters of the left ventricle was observed. Indoor Cycling training in the second phase of cardiac rehabilitation in patients with ischemic heart disease or after myocardial infarction is a safe form of therapy and therefore may be an interesting alternative method to the classic bicycle ergometer exercise in the stage of an early cardiac rehabilitation
Russian Journal of Cardiology 2017, 3 (143): 46-53

http://dx.doi.org/10.15829/1560-4071-2017-3-46-53

Key words: comprehensive cardiac rehabilitation, coronary heart disease, Indoor Cycling, Percutaneous Coronary Intervention, myocardial infarction.

${ }^{1}$ Silesian Centre of Rehabilitation and Prevention, Ustroń; ${ }^{2}$ Academy of Physical Education, Katowice, Poland.

Gloc D.D. ${ }^{*}$ - Doctor of physical culture, $1^{\text {st }}$ Department of Cardiac Rehabilitation, Nowak Z. - Professor of Physical Culture, Faculty of Physiotherapy.

*Автор, ответственный за переписку (Corresponding author): glocdagmara@gmail.com

BSA - body surface area, CABG - coronary artery bypass graft, IVS interventricular septal thickness, LVEDD - left ventricular end diastolic diameter, LVEDV - left ventricular end diastolic volume, LVEF - left ventricular ejection fraction, LVESD - left ventricular end systolic diameter, LVESV - left ventricular end systolic volume, LVM - left ventricular mass, LVMI — left ventricular mass index, LVPW - left ventricular posterior wall thickness, LVSV - left ventricular stroke volume, $\mathrm{PCl}$ - percutaneous coronary intervention.

Рукопись получена 27.06.2016

Рецензия получена 15.07.2016

Принята к публикации 22.07.2016

\section{ВЛИЯНИЕ ВЕЛОТРЕНИРОВОК В ПОМЕЩЕНИИ НА ПАРАМЕТРЫ ГЕМОДИНАМИКИ ЛЕВОГО ЖЕЛУДОЧКА МУЖЧИН С ИШЕМИЧЕСКОЙ БОЛЕЗНЬЮ СЕРДЦА И ПОСЛЕ ИНФАРКТА МИОКАРДА}

\author{
Глоц Д. Д. ${ }^{1}$, Новак $3 .{ }^{2}$
}

Цель. Молодой возраст кардиологических пациентов делает необходимым использование современных форм физической тренировки, становящихся альтернативными и более востребованными путями эффективной реабилитации. Одна из таких форм - тренировка выносливости на велотренажёре в помещении. Текущее исследование предполагает изучить влияние одномесячных велотренировок на гемодинамические параметры левого желудочка мужчин с ишемической болезнью сердца и после инфаркта миокарда.

Материал и методы. Группа исследования включала 50 мужчин в модель А второй фазы сердечно-сосудистой реабилитации (20 мужчин группы велотренажёра (ВТ), 20 реабилитируемых в соответствии с рекомендациями Польского кардиологического общества - стандартная группа (СТ), и 10 человек в группе контроля не участвовали в какой-либо реабилитации). Средний возраст всех пациентов был 56,60ะ8,25 лет, средняя фракция выброса левого желудочка $-56 \% \pm 4,00$.

Результаты. Эхокардиография не показала значимых различий после месяца тренировок в обеих группах кардиореабилитации. В группе отказавшихся от какой-либо реабилитации было показано снижение всех эхокардиографических показателей, включая значимое снижение конечно-диастолического диаметра левого желудочка (52,80 vs 50,50 мм) и объёма (134,85 vs

High prevalence of cardiovascular diseases (on the one hand caused by the adverse impact of civilization, on the other - the increase of survival associated with the dynamic development of medicine, including cardiology) caused an increased significance of secondary prevention
$121,88$ мл; обе переменные с $p<0,001)$, как и массы левого желудочка $(239,46$ vs 208,61 г; p=0,002) и индекса массы левого желудочка (123,52 vs 107,61 г/м²; $\mathrm{p}=0,001)$.

Заключение. Не было показано негативного влияния велотренировок на морфологические параметры левого желудочка. Велотренировки во второй фазе кардиореабилитации пациентов с ишемической болезнью сердца или после инфаркта миокарда - безопасная форма терапии, а потому могут быть интересной альтернативой классическому велоэргометру на стадии ранней кардиореабилитации

Российский кардиологический журнал 2017, 3 (143): 46-53

http://dx.doi.org/10.15829/1560-4071-2017-3-46-53

Ключевые слова: тщательная кардиореабилитация, ишемическая болезнь сердца, велотренировки в помещении, чрескожное коронарное вмешательство, инфаркт миокарда.

${ }^{1}$ Центр реабилитации и профилактики в Силезии, Устронь; 'Академия физической культуры, Катовице, Польша

and rehabilitation. Evaluation of invasive cardiology methods, the use of new surgical techniques and conservative treatment (including dissemination of anticoagulation and fibrinolysis) have contributed to reduction of mortality from cardiovascular diseases [1-3]. 
Table 1

Characteristics of the Indoor Cycling, standard and control group

\begin{tabular}{|c|c|c|c|}
\hline Variable & $\begin{array}{l}\text { Indoor Cycling group } \\
(n=20)\end{array}$ & $\begin{array}{l}\text { Standard group } \\
(n=20)\end{array}$ & $\begin{array}{l}\text { Control group } \\
(n=10)\end{array}$ \\
\hline Age (years) & $\begin{array}{l}57,50 \pm 9,51 \\
(39-72)\end{array}$ & $\begin{array}{l}56,40 \pm 9,85 \\
(40-70)\end{array}$ & $\begin{array}{l}55,40 \pm 8,25 \\
(46-67)\end{array}$ \\
\hline Body height $(\mathrm{cm})$ & $\begin{array}{l}178 \pm 5,46 \\
(168-191\end{array}$ & $\begin{array}{l}176,40 \pm 5,95 \\
(164-190)\end{array}$ & $\begin{array}{l}174,90 \pm 8,03 \\
(164-190)\end{array}$ \\
\hline Body weight (kg) & $\begin{array}{l}84,15 \pm 9,35 \\
(70-104)\end{array}$ & $\begin{array}{l}87,02 \pm 14,08 \\
(66,90-117,90)\end{array}$ & $\begin{array}{l}81,15 \pm 16,27 \\
(63,40-117,30)\end{array}$ \\
\hline $\mathrm{BMI}\left(\mathrm{kg} / \mathrm{m}^{2}\right)$ & $\begin{array}{l}26,58 \pm 2,61 \\
(21,20-32,60)\end{array}$ & $\begin{array}{l}27,84 \pm 3,20 \\
(22,80-34,60)\end{array}$ & $\begin{array}{l}26,29 \pm 3,32 \\
(22,60-32,50)\end{array}$ \\
\hline $\operatorname{LVEF}(\%)$ & $\begin{array}{l}56,05 \pm 3,91 \\
(50-60)\end{array}$ & $\begin{array}{l}56,10 \pm 4,19 \\
(50-68)\end{array}$ & $\begin{array}{l}55,70 \pm 4,00 \\
(50-62)\end{array}$ \\
\hline
\end{tabular}

Abbreviations: BMI — body mass index, LVEF — left ventricular ejection fraction, $\mathrm{n}$ - the number of patients.

Table 2

The type of diseases in the Indoor Cycling, standard and control group

\begin{tabular}{|l|l|l|l|}
\hline Type of disease & $\begin{array}{l}\text { Indoor Cycling group } \\
\mathrm{n}(\%)\end{array}$ & $\begin{array}{l}\text { Standard group } \\
\mathrm{n}(\%)\end{array}$ & $\begin{array}{l}\text { Control group } \\
\mathrm{n}(\%)\end{array}$ \\
\hline Ischemic heart disease & $20(100 \%)$ & $20(100 \%)$ & $10(100 \%)$ \\
\hline Type 2 diabetes & $4(20 \%)$ & $5(25 \%)$ & $2(20 \%)$ \\
\hline Hyperlipidemia & $6(30 \%)$ & $3(15 \%)$ & $0(0 \%)$ \\
\hline Hypertension & $16(80 \%)$ & $17(85 \%)$ & $8(80 \%)$ \\
\hline Myocardial infarction & $16(80 \%$ & $20(100 \%)$ & $5(50 \%)$ \\
\hline Total & $20(100 \%)$ & $10(100 \%)$ & \\
\hline
\end{tabular}

Abbreviation: $\mathrm{n}-$ the number of patients.

Nowadays, primary aim is to reduce mortality, however the purpose is also to counteract secondary prevention of relapse and repeated cardiac episodes, and rehabilitation the desire to restore the full quality of life of the patient, facilitating return to active and family life $[2,4]$. Therefore, logical and desirable seems to be a modification of cardiac rehabilitation, especially applied forms of physical training.

According to Cardiac Rehabilitation Standards of Polish Cardiac Society, traditional and commonly used training forms are endurance training in the form of walking on the treadmill or in the field, a bicycle ergometer training, swimming, training on the lifecycle and anaerobic resistance training. In patients with coronary artery events, both of these forms combined together provided the best results [5-8].

Physical training, which begins in the second stage of cardiac rehabilitation, is well understood and described, but rare publications on the use of modern, innovative forms of exercises for patients with cardiovascular diseases can be found. Younger age of the cardiac patients somehow necessitates the use of modern forms of physical training, which become an interesting and attractive means to provide effective process of recovery [9]. One such form is an endurance training, which in a sense resembles the traditional practice recommended for the second stage of the rehabilitation, but with a slightly different course Indoor Cycling. On the one hand the use of this training will diversify rehabilitation program, on the other, there would be a better possibility to choose an appropriate load depending on the model of improvement [10].

The Indoor Cycling training of healthy individuals has several basic types of profiles - from least, through medium to strongly incriminating. Properly conducted training consists of a warm-up, an appropriate training and an end portion - crossover and stretching, which concerns proper muscle groups and tendons, especially legs, arms and the spine. Indoor Cycling training can be carried out in three basic positions of the hands, in sitting or standing techniques [10-13]. So far, there are no reports of the use of Indoor Cycling training as an alternative form to the traditional and commonly used endurance cycle ergometer training of patients after coronary events, which tends to analyze the effectiveness of this form of physical training. The study attempts to determine the impact of the 22 Indoor Cycling training units (1-month) on hemodynamic parameters of the left ventricle patients' with ischaemic disease or after myocardial infarction.

\section{Material and methods}

The study group consisted of 50 men under the model A of the second phase of cardiac rehabilitation (results of exercise treadmill test $\geq 7$ MET or $100 \mathrm{~W}$ ). Groups were comparable in terms of age, body height, body weight and left ventricular ejection fraction. Their characteristics are 
Table 3

The method of treatment in the Indoor Cycling, standard and control group

\begin{tabular}{|l|l|l|l|}
\hline Method of treatment & $\begin{array}{l}\text { Indoor Cycling group } \\
\mathrm{n}(\%)\end{array}$ & $\begin{array}{l}\text { Standard group } \\
\mathrm{n}(\%)\end{array}$ & $\begin{array}{l}\text { Control group } \\
\mathrm{n}(\%)\end{array}$ \\
\hline $\mathrm{PCl}+$ Stent & $16(80 \%)$ & $17(85 \%)$ & $8(80 \%)$ \\
\hline $\mathrm{PCl}$ & $4(20 \%)$ & $3(15 \%)$ & $2(20 \%)$ \\
\hline Total & $20(100 \%)$ & $20(100 \%)$ & $10(100 \%)$ \\
\hline
\end{tabular}

Abbreviations: $\mathrm{n}$ - the number of patients, $\mathrm{PCl}$ - percutaneous coronary intervention.

Table 4

The number of stents implanted in the Indoor Cycling, standard and control group

\begin{tabular}{|l|l|l|l|}
\hline Number of stents & $\begin{array}{l}\text { Indoor Cycling group } \\
\mathrm{n}(\%)\end{array}$ & $\begin{array}{l}\text { Standard group } \\
\mathrm{n}(\%)\end{array}$ & $\begin{array}{l}\text { Control group } \\
\mathrm{n}(\%)\end{array}$ \\
\hline 0 & $4(20 \%)$ & $3(15 \%)$ & $2(20 \%)$ \\
\hline 1 & $12(60 \%)$ & $5(25 \%)$ & $3(50 \%)$ \\
\hline 2 & $1(5 \%)$ & $1(5 \%)$ & $0(0 \%)$ \\
\hline 3 & $1(5 \%)$ & $1(5 \%)$ & $0(\%)$ \\
\hline 4 and more & $2(10 \%)$ & $20(100 \%)$ & $10(100 \%)$ \\
\hline Total & $20(100 \%)$ & & \\
\hline
\end{tabular}

Abbreviation: $\mathrm{n}-$ the number of patients.

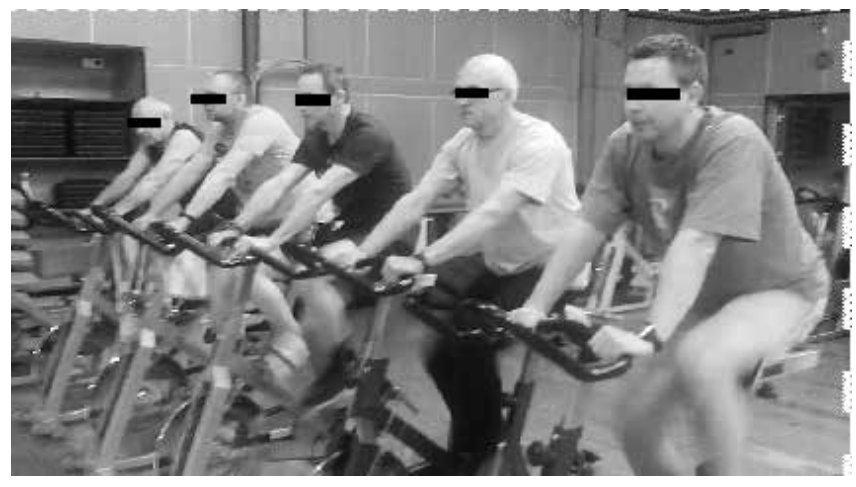

Figure 1. Indoor Cycling training (image by author).

shown in Table $1.100 \%$ of patients experienced ischemic heart disease, $74 \%$ of them had a myocardial infarction (Table 2). The prevailing type of treatment in the study population was percutaneous coronary intervention (PCI) combined with implantation of 1 stent (Table 3 and 4).

Inclusion criteria were: formal consent to participate in the study, stable coronary heart disease or uncomplicated course of myocardial infarction, time of last cardiovascular event not less than 2 months and not more than 6 months, an exercise test results $\geq 7$ MET / $100 \mathrm{~W}$, left ventricular ejection fraction $\geq 50 \%$. Exclusion criteria were: lack of formal consent to participate in the study, recent myocardial infarction, $<2$ months of a cardiovascular event, left ventricular ejection fraction $<50 \%$, the surgical treatment of coronary artery disease $(\mathrm{CABG})$, unregulated hypertension, unstable ischemic heart disease, arrhythmias, diagnosed cancer, diseases of the central or peripheral nervous system, varicose veins of the lower limbs, degenerative disease of the peripheral joints and spine, past unhealed injuries of the lower limbs, advanced peripheral vascular disease, age $\geq 75$ and incomplete medical documentation.

Between November 2014 and January 2015, reducing the number of confounding factors such as age, sex, disease entity, method of treatment, the level of exercise capacity, 50 patients enrolled in the study were allocated according to random selection into the three groups: 20 men, members of the Indoor Cycling group, IC, 20 men rehabilitated accordingly to the recommendations of the Section of Cardiac Rehabilitation and Physiology Effort Polish Cardiac Society - a standard group, ST and 10 people who did not participate in any cardiac rehabilitation program - a control group, C). Patients (except from the $\mathrm{C}$ group) underwent 22 training units performed 5 times a week (1 month). In the ST group the training included: endurance exercise on a bicycle ergometer, resistance training and calisthenics (general exercises). Whereas men in the IC group, instead of the traditional interval training on the ergometer, participated in the Indoor Cycling lessons arranged by the same instructor (Table 5, Figure 1). That group also participated in the other two types of trainings (resistance and calisthenics) according to the standards (Table 6). Heart rate frequency was constantly individually monitored during each lesson by the heart rate monitor (Polar FT1), as well as by the instructor.

At baseline and at the end of the rehabilitation period all patients underwent echocardiographic measurements, where the left ventricular mass was calculated as defined underneath.

The echocardiographic evaluation was performed with the patient lying in the left decubitus position, by one 
Table 5

The protocol of the Indoor Cycling training unit

\begin{tabular}{|c|c|c|c|c|}
\hline Part of the training session & Time (min) & Borg scale & RPM & Position/technique \\
\hline Warm-up & $1-5$ & $9-10$ & $100-110$ & $\begin{array}{l}\text { Position } 2\left(2 \frac{1}{2} \mathrm{~min}\right) \\
\text { Position } 1-\mathrm{SF}\left(2 \frac{1}{2} \mathrm{~min}\right)\end{array}$ \\
\hline \multirow[t]{4}{*}{ Appropriate training } & $5-10$ & $12-13$ & $\begin{array}{l}110 \\
110 \\
80\end{array}$ & $\begin{array}{l}\text { Position } 1 \text { ( } 2 \mathrm{~min}) \\
\text { Position } 2 \text { (2 min) } \\
\text { Position } 2-\mathrm{SC} \text { ( } 1 \mathrm{~min})\end{array}$ \\
\hline & $10-17,5$ & $12-14$ & $\begin{array}{l}80 \\
100-110 \\
100 \\
80-100 \\
100\end{array}$ & $\begin{array}{l}\text { Position } 3-\mathrm{StC}(1 / 2 \mathrm{~min}) \\
\text { Position } 1\left(2 \frac{1}{2} \mathrm{~min}\right) \\
\text { Position } 2\left(2 \frac{1}{2} \mathrm{~min}\right) \\
\text { Pozycja } 2-\mathrm{StF}\left(1 \frac{1}{2} \mathrm{~min}\right) \\
\left.\text { Position } 1 \text { ( } 1 \frac{1}{2} \mathrm{~min}\right)\end{array}$ \\
\hline & $17,5-22,5$ & $13-14$ & $\begin{array}{l}60-80 \\
100 \\
80\end{array}$ & $\begin{array}{l}\text { Position } 2-\mathrm{SC}(1 \mathrm{~min}) \\
\text { Position } 2\left(3 \frac{1}{2} \mathrm{~min}\right) \\
\text { Position } 3-\mathrm{StC}(1 / 2 \mathrm{~min})\end{array}$ \\
\hline & $22,5-27,5$ & $12-13$ & $\begin{array}{l}80 \\
80 \\
100-110\end{array}$ & $\begin{array}{l}\text { Position } 2 \text { (2 min) } \\
\text { Position } 2-\mathrm{SC}(2 \mathrm{~min}) \\
\text { Position } 2 \text { (1 min) }\end{array}$ \\
\hline Cool down & $27,5-30$ & $9-10$ & 100 & Position 1 - SF \\
\hline Stretching & $30-35$ & 9 & - & - \\
\hline
\end{tabular}

Abbreviations: min - minute, position 1 - close, position 2 - open, position 3 - forward, RPM - Revolutions Per Minute, SC - Seated Climb, SF - Seated Flat, StC Standing Climb, StF - Standing Flat.

Table 6

\section{Methodology of training according to the recommendations of the Section of Cardiac Rehabilitation and Physiology Effort Polish Cardiac Society}

\begin{tabular}{|l|l|l|}
\hline $\begin{array}{l}\text { The type of training } \\
\text { Endurance training }\end{array}$ & Methodology & Workload \\
\hline & $\begin{array}{l}\text { Training on a bicycle ergometer, } \\
5 \text { times a week } \\
30 \text { minutes }\end{array}$ & $\begin{array}{l}\text { The workload applied on the basis of calculation of heart } \\
\text { rate training, starting from } 60 \% \text { of heart rate reserve } \\
\text { increased by } 10 \% \text { after } 5 \text { units of training, to } 80 \% \text { of heart } \\
\text { rate reserve, } 14 \text { degrees of subjective scale } \\
\text { effort assessment by the Borg scale }\end{array}$ \\
\hline Resistance training & $\begin{array}{l}\text { Exercises in the form of training station, } \\
5 \text { times a week } \\
30 \text { minutes } \\
\text { Eeneral exercises }\end{array}$ & $\begin{array}{l}\text { Exercises in the gym - elements of aerobic and anaerobic training, } \\
\text { stretching, breathing exercises, } \\
5 \text { times a week } \\
30 \text { minutes }\end{array}$ \\
\hline
\end{tabular}

cardiologist who was unaware of the study protocol (using Philips ALT HDI 3000). Left ventricular end diastolic diameter (LVEDD), left ventricular end systolic diameter (LVESD), interventricular septal thickness (IVS), posterior wall thickness (LVPW) were measured in all patients from the left parasternal long axis. Left ventricular ejection fraction (LVEF), left ventricular end diastolic volume (LVEDV), left ventricular end systolic volume (LVESV), LVEDD and LVESD were measured according to Simpson's model. Left ventricular mass (LVM) was calculated with the use of the anatomically validated formula:

$\mathrm{LVM}=0,8\left(1,04 \times\left[(\text { LVEDD }+ \text { IVS }+ \text { LVPW })^{3}-\right.\right.$ LVEDD $\left.\left.^{3}\right]\right)+0,6$

Left ventricular mass was divided by body surface area (BSA) to obtain the left ventricular mass index (LVMI), according the Devereaux formula [14]:

$$
\mathrm{LVMI}=\mathrm{LVM} / \mathrm{BSA}
$$

while body surface area was calculated using the following formula:

$\mathrm{BSA}=$ weight $0,425 \times$ height $0,725 \times 71,84$

Left ventricular stroke volume (LVSV) was calculated with the use of formula:

LVSV = LVEDD - LVESD.

The study was performed according to the Good Clinical Practice guidelines and the Declaration of Helsinki. The study protocol was approved by the local Committee of Ethics of the Academy of Physical Education in Katowice - Poland (The Resolution No. 6/2014 of 15.05.2014). Written informed consent was obtained from all participants prior to their inclusion in the study.

For all numerical parameters the arithmetic mean, minimum, maximum and standard deviation were calculated. For the presentation of qualitative data the prevalence of studied traits were used. In order to verify assumptions of tests the Shapiro-Wilk normality test was performed. For the 
Table 7

\section{Results of the echocardiography test in three groups of patients before (I) and at the end (II) of cardiac rehabilitation}

\begin{tabular}{|c|c|c|c|c|c|c|}
\hline Variable & $\begin{array}{l}\text { Indoor Cycling group } \\
(n=20)\end{array}$ & $p$ & $\begin{array}{l}\text { Standard group } \\
(n=20)\end{array}$ & $p$ & $\begin{array}{l}\text { Control group } \\
(n=10)\end{array}$ & $p$ \\
\hline $\begin{array}{l}\text { LVEDD I } \\
\text { LVEDD II } \\
\Delta \\
(\mathrm{mm})\end{array}$ & $\begin{array}{l}49,20 \pm 4,80 \\
49,35 \pm 4,64 \\
0,15^{\# \#}\end{array}$ & 0,998 & $\begin{array}{l}51,20 \pm 4,52 \\
51,25 \pm 4,26 \\
0,05^{\# \#}\end{array}$ & 0,999 & $\begin{array}{l}52,80 \pm 3,36 \\
50,50 \pm 3,77 \\
-2,30\end{array}$ & 0,000 \\
\hline $\begin{array}{l}\text { LVESD I } \\
\text { LVESD II } \\
\Delta \\
(\mathrm{mm})\end{array}$ & $\begin{array}{l}33,10 \pm 3,64 \\
33,55 \pm 3,80 \\
0,45\end{array}$ & 0,956 & $\begin{array}{l}34,15 \pm 3,76 \\
34,85 \pm 3,88 \\
0,70\end{array}$ & 0,773 & $\begin{array}{l}34,80 \pm 3,82 \\
33,60 \pm 4,19 \\
-1,20\end{array}$ & 0,603 \\
\hline $\begin{array}{l}\text { LVESV I } \\
\text { LVESV II } \\
\Delta \\
(\mathrm{ml})\end{array}$ & $\begin{array}{l}45,27 \pm 11,44 \\
46,51 \pm 12,87 \\
1,24\end{array}$ & 0,982 & $\begin{array}{l}48,81 \pm 12,74 \\
51,28 \pm 13,29 \\
2,47\end{array}$ & 0,752 & $\begin{array}{l}51,02 \pm 12,88 \\
47,13 \pm 14,43 \\
-3,89\end{array}$ & 0,654 \\
\hline $\begin{array}{l}\text { LVEDV I } \\
\text { LVEDV II } \\
\Delta \\
(\mathrm{ml})\end{array}$ & $\begin{array}{l}115,37 \pm 25,51 \\
116,08 \pm 24,90 \\
0,71^{* *}\end{array}$ & 0,999 & $\begin{array}{l}126,25 \pm 25,17 \\
126,39 \pm 24,18 \\
0,14^{\star *}\end{array}$ & 1,000 & $\begin{array}{l}134,85 \pm 18,91 \\
121,88 \pm 19,56 \\
-12,98\end{array}$ & 0,000 \\
\hline $\begin{array}{l}\text { LVSV I } \\
\text { LVSV II } \\
\Delta \\
(\mathrm{ml})\end{array}$ & $\begin{array}{l}84,81 \pm 27,60 \\
84,37 \pm 26,77 \\
-0,44\end{array}$ & 0,999 & $\begin{array}{l}95,97 \pm 31,43 \\
93,46 \pm 28,94 \\
-2,51\end{array}$ & 0,975 & $\begin{array}{l}105,27 \pm 24,44 \\
91,10 \pm 25,82 \\
-14,17\end{array}$ & 0,052 \\
\hline $\begin{array}{l}\text { LVEF I } \\
\text { LVEF II } \\
\Delta \\
(\%)\end{array}$ & $\begin{array}{l}56,05 \pm 3,91 \\
57,20 \pm 3,28 \\
1,15\end{array}$ & 0,287 & $\begin{array}{l}56,10 \pm 4,19 \\
57,35 \pm 4,47 \\
1,25^{\star}\end{array}$ & 0,206 & $\begin{array}{l}55,70 \pm 4,00 \\
54,30 \pm 4,54 \\
-1,40\end{array}$ & 0,452 \\
\hline $\begin{array}{l}\text { LVM I } \\
\text { LVM II } \\
\Delta \\
\text { (g) }\end{array}$ & $\begin{array}{l}183,03 \pm 35,75 \\
183,14 \pm 37,03 \\
0,11 \&\end{array}$ & 1,000 & $\begin{array}{l}198,19 \pm 36,21 \\
202,72 \pm 40,41 \\
4,53 \& \&\end{array}$ & 0,955 & $\begin{array}{l}239,46 \pm 208,61 \\
208,61 \pm 47,84 \\
-30,85\end{array}$ & 0,002 \\
\hline $\begin{array}{l}\text { LVMI I } \\
\text { LVMI II } \\
\Delta \\
\left(\mathrm{g} / \mathrm{m}^{2}\right)\end{array}$ & $\begin{array}{l}90,73 \pm 17,09 \\
91,48 \pm 18,34 \\
0,75 \% \%\end{array}$ & 0,997 & $\begin{array}{l}97,47 \pm 15,77 \\
100,00 \pm 14,94 \\
2,53 \% \%\end{array}$ & 0,933 & $\begin{array}{l}123,52 \pm 38,63 \\
107,61 \pm 30,58 \\
-15,91\end{array}$ & 0,001 \\
\hline
\end{tabular}

Annotations: All data are presented as means \pm standard deviation and the difference $\left(\Delta-\right.$ delta). ${ }^{\# \#}-0,003$ IC vs C and 0,005 ST vs C, ** $-0,004$ IC vs C and 0,006 ST vs $C,{ }^{*}-0,045$ ST vs $C, \&-0,014$ IC vs $C, \& \&-0,004$ ST vs $C, \% \%-0,008$ IC vs $C$ and 0,003 ST vs $C$.

Abbreviations: $p$ - level of statistical significance ( $p \leq 0,05$ for the lowest accepted), LVEDD - left ventricular end diastolic diameter, LVEDV - left ventricular end diastolic volume, LVEF - left ventricular ejection fraction, LVESD - left ventricular end systolic diameter, LVESV - left ventricular end systolic volume, LVSV — left ventricular stroke volume, LVM - left ventricular mass, LVMI - left ventricular mass index.

analysis of relationships between variables ANOVA KruskallWallis analysis was used. Assessing the relevance between arithmetic's the Tukey post hoc test was made. All data were analyzed with Statistica software (data analysis software system, version 12.0, StatSoft, Inc. 2015, www.statsoft.com). Statistical significance was defined as $p \leq 0,05$.

\section{Results}

The Table 7 shows results of the echocardiographic measurements in the three groups of patients before (I) and at the end (II) of cardiac rehabilitation.

Echocardiogram did not show significant changes after 1-month of training in Indoor Cycling and standard group. Noteworthy is, that in both groups undergoing comprehensive cardiac rehabilitation value of the LVEF was insignificantly higher than in the beginning $(56,05$ vs $57,20 \%$ in IC group and 56,10 vs $57,35 \%$ in ST group).
Paralleled to the preliminary study in the group of patients who refused to participate in the cardiac rehabilitation, results showed a reduction in all echocardiographic parameters, including a significant decrease in the LVEDD $(52,80$ vs $50,50 \mathrm{~mm})$ and the LVEDV (134,85 vs $121,88 \mathrm{ml}$; both variables at $\mathrm{p}<0,001)$, as well as in the LVM $(239,46$ vs $208,61 \mathrm{~g} ; \mathrm{p}=0,002)$ and the LVMI $\left(123,52\right.$ vs $107,61 \mathrm{~g} / \mathrm{m}^{2}$; $\mathrm{p}=0,001$ ).

The analysis also showed significant differences in $\Delta$ results between groups ( $\Delta$ of LVEDD, LVEDV, LVM and LVMI between IC, S and C group, as well as in $\triangle$ of LVEF among standard and control group).

\section{Discussion}

Echocardiography is considered a clinically relevant, non-invasive structures and function of the heart evaluation. Echocardiography should precede qualification 
for rehabilitation because of the non-invasive character of the assessment of important parameters affecting the safety of its course (left ventricle ejection fraction or indicators of abnormal pressure and blood flow within the heart muscle cavities).

The result of myocardial infarction and coronary artery disease is the impairment of mechanical myocardial function and progressive structural changes in the heart muscle (called remodeling), which affect all parts of the cardiovascular system equally [15]. Altered hemodynamic conditions (for instance reduction of stroke volume, enhancement of end-diastolic volume) and neurohormonal disorders (increased activity of the renin-angiotensinaldosterone as well as catecholamines) consistently contribute to impaired diastolic function of the heart, thus affecting systolic function with reduction of LVEF at the same time. Postinfarction cardiac remodeling, specifically - larger figure of the left ventricle may be an important factor for an unfavorable prognosis, and therefore assess its dimensions and functions should be performed routinely in most cardiac diseases [16]. In turn, postinfarction extension of the right ventricle can indicate the pressure and volume overload $[15,16]$.

This paper presents an evaluation of left ventricular myocardium indicators. Our analysis shown insignificant increases in average values of LVEDD, LVESD, LVEDV, LVESV, LVM, LVMI, LVEF, and minor decrease of left LVSV in both rehabilitated groups after 22 training units. In turn, in the group of patients who refused to participate in the comprehensive cardiac rehabilitation achieved reduction of all these indicators and occurred significant changes in the case of LVEDD, LVEDV, LVM and LVMI. It should be emphasized that determine the influence of physical activity (primarily an endurance type) on postinfarction structure and functions of left ventricle remains still ambiguous [17]. Primarily, the causes of this problem may be differences in the methodology of the study carried out by subsequent authors (factors such as: selection of the population, the extent of myocardial infarction, age of the respondents, the period covered by the observation, measurement techniques and the combination of all mentioned factors as possible).

According to the Karpiński and Witkowska (2009) the end systolic volume in patients after myocardial infarction is strongly correlated with mortality and the incidence of postinfarction heart failure [15]. In the other site, Korzeniowska-Kubacka et al. (2010) claim that the left ventricular diastolic function may be an important factor of an increase in exercise tolerance after a period of rehabilitation [18]. It is not resolved whether exercise training used in cardiac rehabilitation can improve diastolic function of the left ventricle [18]. Gates et al. (2003) noted that regular physical activity does not stimulate changes in diastolic function of the left ventricle in healthy aging men. Observation of Gates et al. coincident with the result obtained in our control group, in which after the observation period was a significant reduction in both the LVEDD and the LVEDV $(p<0,001)$ [19]. Belardinelli et al. (2001) did not notice significant changes in the left ventricle diastolic function in physically active patients compared with inactive, in the course of the 6-month follow-up. However, they differed significantly in the LVESV after this period (40,8 in training group vs $48,8 \mathrm{ml}$ in inactive group; $\mathrm{p}<0,009)$. Whereas the indicator which clearly differentiating patients after 6 months observation was the LVEF. Authors noted that in active patients LVEF increased from 52,3 to $57,3 \%$, while in sedentary lifestyle patients LVEF slightly reduced from 50,2 to $49,3 \%$, which is consistent with changes observed in our analysis [20].

LVEF is a clinical indicator of global myocardial contractility and pumping action. Moreover, it is one of the most important prognostic parameters in patients after myocardial infarction [21, 22]. Postinfarction myocardial range of the left ventricle remodeling can be measured by the LVEF obtained from the echocardiogram. Among the many advantages of comprehensive cardiac rehabilitation, positive impact on this indicator is also mentioned [6].

Sadeghi et al. (2013) analyzed the impact of 8-week cardiac rehabilitation program in 70 patients with ischemic heart disease and left ventricular dysfunction. Authors evaluated changes in indicators such as: LVEF, LVESD and LVEDD. Mentioned authors demonstrated that the LVEF increased significantly from 45,14 to $50,44 \%$ $(\mathrm{p}<0,001)$. However, there were no significant changes in the LVEDD (54,63 vs 53,86 $\mathrm{mm})$ and the LVESD $(38,91$ vs $38,09 \mathrm{~mm}$ ) parameters after the rehabilitation program. Therefore, authors concluded that exercise training in patients with ventricular dysfunction may have beneficial effects on cardiac function, at the same time without adversely affecting the reconstruction of the left ventricle and causing no serious cardiac complications [23]. Similar results obtained Nowak et al. (2010) who after the 6-month follow-up reported a significant increase in the LVEF $(51,64$ vs $52,45 \%, \mathrm{p}<0,02)$ and no significant changes in the LVEDD (51,10 vs 51,35 mm) and LVESD (34,93 vs $34,33 \mathrm{~mm}$ ) indicators [24]. The direction of changes observed by these authors is consistent with our results in which LVEDD and LVESD parameters were not significantly different after 22 training units in the Indoor Cycling and standard group and the LVEF value of these groups was an irrelevant, but still an increase of more than $1 \%$. In patients undergoing comprehensive cardiac rehabilitation are expected to further increase in LVEF parameter in accordance with the fact of the left ventricular contractility improvement.

Haddadzadeh et al. (2011) in turn, analyzed the effectiveness of individually selected program of cardiac rehabilitation in 42 patients with coronary heart disease. The authors obtained a significant improvement of the LVEF in patients receiving 12-week program for rehabilitation enriched by the exercise training (46,9 vs $61,5 \% ; p=0,001)$, compared to the control group, which 
lacked an element of physical activity in rehabilitation program $(47,9$ vs $47,6 \%)$ [21]. On the other hand, Markuszewski et al. (2006) evaluated the impact of type 2 diabetes on postinfarction myocardial remodeling in patients after myocardial infarction with ST-segment elevation treated by percutaneous transluminal coronary angioplasty (PTCA). Authors compared the changes in the parameters of the left ventricle - LVEF, LVEDV, LVESV in 110 people. It has been shown that after 3 months of myocardial infarction in patients with type 2 diabetes and patients without that disease was significantly reduced LVEF and significantly increased LVESV value. Because patients with diabetes often suffer from other conditions such as hypertension and obesity as well as a biochemical metabolic disorders which have a negative impact on left ventricular diastolic function are occurred equally, in the case of such patients should be considered implementation of controlled and systematic physical activity. Negative changes observed in the Markuszewski et al. analysis were not present in our work, in which type 2 diabetes occurred in $22 \%$ of the total study population [22].

Further analyzed indicators were the LVM and the LVMI. According to Nowak (2006) LVM is an independent prognostic factor of overall mortality from cardiac causes and complications of coronary artery disease in people over the age of 40 and LVMI - used to assess the degree of left ventricular myocardium hypertrophy [25]. LVM is proportional to the body. It can refer to the weight $(\mathrm{kg})$ growth $(\mathrm{m})$ or body surface area $\left(\mathrm{m}^{2}\right)$. The increase of LVM resulting from the hypertrophy is an important risk factor for heart failure and reduction of LVEF value [16]. According to Pitsavos et al. (2011) physical activity associated with leisure time is correlated with reduction of the LVM. Our analysis showed a slight increase in LVM and LVMI in both cardiac comprehensive rehabilitation groups. Noteworthy is fact that in the Indoor Cycling and standard group average value of LVMI was lower than 116 $\mathrm{kg} / \mathrm{m}^{2}$ classified as a moderate left ventricular hypertrophy [26]. An interesting change can be observed in the case of patients who refused to participate in the rehabilitation program, in which the average value of LVMI was significantly reduced $\left(123,52 \mathrm{vs} 107,61 \mathrm{~g} / \mathrm{m}^{2} ; \mathrm{p}=0,001\right)$, as well as LVM (239,46 vs $208,61 \mathrm{~g} ; \mathrm{p}=0,002)$. These observations differ from the analysis Pitsavos et al. (2011), who evaluated the effect of a regular 16-week physical training on the cardiovascular system of middle age men

\section{References}

1. Dudek D, Legutko J, Siudak Z, et al. Organizacja interwencyjnego leczenia pacjentów Z zawałem serca STEMI i NSTEMI w Polsce. Kardiol Pol, 2010; 68, 5: 618-24.

2. Jerka K, Kurpesa M. Rehabilitacja kardiologiczna po zawale mięśnia sercowego przegląd aktualnych doniesień. Pol Przegl Kardiol, 2012; 14(2): 138-41.

3. Kochman W, Sukiennik A, Radomski M. Zawał serca - aktualne standardy leczenia. Folia Cardiol Excerpta, 2009; 4(4), 204-11.

4. Piepoli MF, Corra U, Benzer W, et al. Secondary prevention through cardiac rehabilitation: physical activity counselling and exercise training. Eur Heart J, 2010; 31: 1967-76.

5. Węgrzynowska-Teodorczyk K, Jankowska EA, Banasiak W, et al. Znaczenie treningu oporowego w redukcji mięśniowych następstw niewydolności serca. Kardiol Polska, 2008; 66: $434-42$. with normal or moderately elevated blood pressure. It should be emphasized, that these patients had no clinical signs of coronary artery disease, which in the case of the control group in our analysis, is essential. After the observation period the average value of LVM and LVMI in physically active group significantly decreased $(225,10$ vs $181,87 \mathrm{~g}$ and 118,80 vs $96,10 \mathrm{~g} / \mathrm{m}^{2}$, both changes at $\mathrm{p}<0,05$ ), while in a group of physically inactive these indicators enhanced $(227,73$ vs $231,13 \mathrm{~g}$; $\mathrm{p}<0,05,115,94$ vs $117,52 \mathrm{~g} / \mathrm{m}^{2}$ ) [26]. Nowak et al. (2010) in turn, obtained small and insignificant loss of left ventricular mass and left ventricular mass index in patients (sequentially 210,64 vs $207,86 \mathrm{~g}$ and 110,82 vs $109,86 \mathrm{~g} / \mathrm{m}^{2}$ ), which the authors substantiating the influence of too short observation period what is consistent with the results of our analysis [24].

The overall conclusion is that the effect of exercise training on myocardium has not been clearly explained yet. In most studies, as in the present could not be demonstrated a significant influence of exercise training on the morphological and functional ventricular parameters or confirmed that physical activity improved it irrelevantly (in particular, with reference to a preferred change in left ventricle ejection fraction). However, it should be noted that in the control groups, which have not undergone training often been reported deterioration of left ventricular function of the heart muscle during the observation period.

\section{Conclusion}

In conclusion, no negative impact of the Indoor Cycling training on morphological parameters of left ventricle of men with ischemic heart disease or after myocardial infarction was found. Analysis shown that Indoor Cycling is a safe, engaging, effective and welltolerated form of endurance training, which would expand the range of activities recommended in the comprehensive cardiac rehabilitation beginning in the second stage. Further studies are needed to define the long-term effects of use this form of physical activity as well as the introduction of Indoor Cycling in women after coronary events.

Acknowledgements. The results of the paper are part of $\mathrm{PhD}$ thesis of Dagmara Gloc. There were no grants, no external financial or technical support or other assistance during the evaluation of the paper. Conflict of interest none declared.

6. Bromboszcz J, Dendura M. Miejsce aktywności fizycznej w programie rehabilitacji kardiologicznej. [In:] Rehabilitacja kardiologiczna - stosowanie ćwiczeń fizycznych. Bromboszcz J., Dylewicz P. (red.). ELIPSA-JAIM s.c., Kraków 2009: 41-58.

7. Pitsavos $\mathrm{Ch}$, Chrysohoou Ch, Koutroumbi M, et al. The impact of moderate aerobic physical training on left ventricular mass, exercise capacity and blood pressure response during treadmill testing in borderline and mildly hypertensive males. Hell J Cardiol, 2011; 52: 6-14.

8. Sobieszczańska M, Kałka D, Pilecki W, Adamus J. Aktywność fizyczna w podstawowej i pierwotnej prewencji choroby sercowo-naczyniowej. Pol Merkuriusz Lek, 2009; 26(156): 659-64.

9. Niewiadomski P, Nowak Z, Cembrzyńska J, Frydrych-Mazur K. Współczesne formy treningu stosowane w II i III etapie rehabilitacji kardiologicznej. Rehabil Prakt, 2010; 3: 24-8. 
10. Gloc $D$, Nowak $Z$. The impact of Indoor Cycling training on exercise capacity and blood lipid profile of men with ischaemic heart disease or after myocardial infarction. Russ $\mathrm{J}$ Cardiol 2016, 4 (132), Engl.: 153-9.

11. Bielecki T, Krawczyk K, Skowroński R. Spinning uniwersalny. Zestaw ćwiczeń na spinningowym rowerze stacjonarnym. Uniwersytet Marii Curie-Skłodowskiej, Lublin 2010.

12. Günther M. Indoor-Cycling: optimal trainieren für Kondition und Figur. Gräfe und Unzer, München 2004

13. Schmidt A. Indoor-Cycling. Meyer \& Meyer Verlag, Aachen 2008.

14. Devereux RB, Reichek N. Echocardiographic determination of left ventricular mass in man. Anatomic validation of the method. Circulation, $1977 ; 55: 613-8$.

15. Karpiński $\measuredangle$, Witkowska M. Pozawałowa przebudowa serca - konsekwencje kliniczne. Przegl Lek, 2009; 66(8): 380-3.

16. $\mathrm{OH} \mathrm{JK}$, Seward JB, Tajik AJ. Ocena funkcji skurczowej i wielkości jam serca. [In:] Podręcznik echokardiografii. Wydanie Polskie. Kasprzak JD (red.). MediPage 2008: 115-26.

17. Sadeghi M, Garakyaraghi M, Khosravi M, et al. The impacts of cardiac rehabilitation program on echocardiographic parameters in coronary artery disease patients with left ventricular dysfunction. Cardiol Res Pract: 2013, article ID 201713, 4 pages. http://dx.doi. org/10.1155/2013/201713 (access: 05.04.2015).

18. Korzeniowska-Kubacka I, Bilińska M, Michalak E, et al. Wpływ treningu fizycznego na funkcję rozkurczową lewej komory serca i jej związek z wydolnością fizyczną u pacjentów po zawale serca. Folia Cardiol Excerpta, 2010; 5(4): 170-7.

19. Gates PE, Tanaka H, Graves J, Seals DR. Left ventricular structure and diastolic function with human ageing. Relation to habitual exercise and arterial stiffness. Eur Heart J, 2003; 24(24): 2213-20.
20. Belardinelli R, Paolini I, Cianci G, et al. Exercise training intervention after coronary angioplasty: The ETICA Trial. J Am Coll Cardiol, 2001; 37(7): 1891-900.

21. Haddadzadeh MH, Maiya AG, Padmakumar R, et al. Effect of exercise-based cardiac rehabilitation on ejection fraction in coronary artery disease patients: a randomized controlled trial. Heart Views, 2011; 12(2): 51-7.

22. Markuszewski L, Pietruszyński R, Kamiński G, Grabowicz W. Echokardiograficzne zmiany u chorych na cukrzyce typu 2 po przebytym zawale serca z uniesieniem odcinka ST, leczonych pierwotną przezskórną angioplastyką wieńcową. Folia Cardiol Excerpta, 2006; 1(2): 110-5.

23. Sadeghi M, Garakyaraghi M, Khosravi M, et al. The impacts of cardiac rehabilitation program on echocardiographic parameters in coronary artery disease patients with left ventricular dysfunction. Cardiol Res Pract: 2013, article ID 201713, 4 pages. http://dx.doi. org/10.1155/2013/201713 (access: 05.04.2015).

24. NowakZ, Plewa M, Skowron M, etal. Minnesota Leisure Time Physical Activity Questionnaire as an additional tool in clinical assessment of patients undergoing Percutaneous Coronary Interventions. J Hum Kinet, 2010; 23: 79-87.

25. Nowak Z. Prospektywna ocena przydatności kwestionariuszy aktywności fizycznej u chorych poddanych interwencjom wieńcowym. AWF, Katowice 2006.

26. Pitsavos $\mathrm{Ch}$, Chrysohoou $\mathrm{Ch}$, Koutroumbi $\mathrm{M}$, et al. The impact of moderate aerobic physical training on left ventricular mass, exercise capacity and blood pressure response during treadmill testing in borderline and mildly hypertensive males. Hellenic $\mathrm{J}$ Cardiol, 2011; 52: 6-14. 